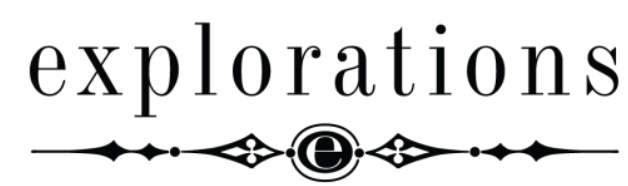

Explorations: A Journal of Language and Literature

\title{
INTERVIEW
}

\section{Fussing and fiddling}

Jacek Gutorow in conversation with Christopher Reid

DOI: $10.25167 / \mathrm{EXP} 13.20 .8 .1$

Jacek Gutorow: Do you remember your first published poem?

Christopher Reid: This takes me back a long way. I think I must have felt my first excitement about poetry, the excitement of discovery, when I was about seven. There were certainly nursery rhymes before that, as part of the general background and atmosphere of infancy, and I enjoyed them - still do - but I'm thinking of poetry on the page. My parents had a book of selections from the magazine Punch, mainly cartoons and humorous articles, which I first of all enjoyed for the cartoons, as I did comical drawings of my own then, but there was the occasional piece of light verse as well, and I found myself entranced by them. I didn't understand them, of course; nor could I tell that they were flimsy, without quality; but I was very taken by what I could see was a use of words that wasn't like ordinary writing, but was a sort of playfulness, rather. A permission to escape from the ordinary. So you could do that with words, could you? How thrilling! I learned one or two of these light verses by heart, then recited one at school, to the mockery of my class mates. Their contempt didn't put me off: I was hooked. Then I suppose I must have started trying to write the same sort of thing. My first success was at the age of eight, when our Sunday school teacher told us to go home and write about something we had learned in our lessons, which were mainly Bible stories. I chose Jeremiah and Nebuchadnezzar, because I liked the names and liked the idea of finding rhymes for them. So I wrote a six-line poem which went as follows:

There was once a prophet called Jeremiah,

Of the coming of the Lord he was no denier.

He spoke to his people about the coming of the Lord,

But the people were not in the least absorbed.

They went on living in their leisure

Until they were conquered by Nebuchadnezzar.

I brought that back the following Sunday and it was printed in the parish magazine and became my first publication.

Explorations: A Journal of Language and Literature, 8 (2020), pp. 2-15 
JG: You have published several books of poems for children. They show your enchantment with language, its inventiveness and unpredictability. Actually, they read as if they were written from a child's perspective and with a child's sensibility.

CR: That's a fascinating observation, about the child's perspective. If it's true, I'm delighted. I think there's plenty of my old child self still in me, but the odd thing about that is the length of time it took to find expression in poems. I remember that for quite a while I used to tell myself I would never write poems for children, even if I wanted to, because I had gone too far past childhood and had lost access to it in the process. Then one morning, in my early fifties, I was sitting at breakfast, with the Collected Poems of Vasko Popa next to my plate, and I opened it and there was his 'Hen', from a set of early poems that he wrote about farm animals. Of course, Popa never intended it for children, absolutely not, but somehow it ignited a childish response in me and that day I wrote 'Questioning a Hen', in which I imagine the sun as a fiery hen making its way through the sky in order to lay a stone egg, which is the moon. The questioner in the poem is a child and the hen/sun replies rather loftily and condescendingly. When I got that down on the page, I just wanted to write more and more, and about a month later I had all the poems that would appear in my first book for children, All Sorts.

JG: As a child, were you fascinated with words and letters? In many poems you seem to enjoy language on a very basic level, finding pleasure in how it works or in the shapes and sounds of speech.

CR: Yes, I was fascinated. I'm told I learned the alphabet very young, and one clear early memory is of the small blackboard on which I formed my first letters and which had the alphabet printed around its edge. I must have been born with that appetite waiting to be satisfied. You might think of it as a sort of greed for learning, which has always been with me, or in me. So that immature relish is still alive. My feeling for words is almost fetishistic: not just their sound, but their shape and weight, their tactility, matter to me supremely as I put a poem together. Thinking about all that is as much a driving force in my writing as the need to get a story across or to lay out a reasoned argument.

JG: When did you start reading poetry and who were the first authors you felt were worth the effort?

CR: A lot of my reading at school was poetry, and not just in English. We began to be taught Latin at the age of nine, then Ancient Greek at eleven. In our English lessons we were introduced to poems out of Palgrave's Golden Treasury and other anthologies, and one of the tasks we were set was to write parodies of well-known poems. That struck me as the greatest fun in the world, very different from the rest of homework. Auden says somewhere that, if he were called on to design a course for apprentice poets, he would command them to do just two things: memorise a lot of verse, and write a lot of parodies. Our prep school English teacher seems, by a stroke of genius, to have had the same idea. The fare he gave us to read was largely the Romantic and Victorian greats, and left-overs from the nineteenth century like Chesterton and Newbolt, but that was no hardship - we were young and with indiscriminate appetites for learning. Things changed later, at 
secondary level, when exam syllabuses presented a wider range of reading but without leaving room for frivolous activities like parody. But I suppose the occasional poem I wrote then still had an element of parody, or at least imitation, about it, and I went through phases of trying to sound like Dylan Thomas or Edith Sitwell - twentieth-century figures with a more gaudy rhetoric than you could get away with these days. The seventeenth-century so-called Metaphysical poets - Donne, Herbert, Marvell - also strongly caught my fancy. They require no apology at all, and even with Thomas and Sitwell I still feel a fondness and respect and can't in my heart dismiss them utterly, as many of my contemporaries would.

JG: How about the tradition of the so-called nonsense verse? I'm thinking of Edward Lear and Lewis Carroll, or even (why not) John Lennon.

CR: Both those Victorians appealed to me from an early age. I was enchanted by the Alice books, and not just the prose and poems but Tenniel's illustrations as well. Together, they evoked a world that I knew was unreal but that felt like somewhere that could be physically entered, in much the same way as Alice herself enters it, down a rabbit hole or through a mirror. A very disturbing world, obviously, but irresistibly enticing; I wanted to go there again and again. Lear's appeal was different: he addresses you through the emotions, feelings of loss, a prevailing melancholy, whereas Carroll is ruthlessly logical. I think you need both aspects for the full picture. John Lennon - yes, why not? In His Own Write came out while I was at school and I happily enjoyed the silliness. But a deeper source for me then - and a more rumbustious and roundly embodied expression of the nonsense spirit - was a radio programme called The Goon Show, written by Spike Milligan and performed by him, Peter Sellers and Harry Secombe. The world they conjured up was as palpable to me as that of Alice's Adventures. Radio, which deals necessarily in sound, whether verbal or mere noise, can be a great educator of poets. Milligan's brain was manically fertile. He also, later on, wrote poems for children - nonsense, again - but they never had the impact on me that the outrageous lunacy of The Goon Show did. All three performers were musically gifted and they deployed their voices to make a kind of exuberant but disciplined jazz.

JG: Your debut volume Arcadia was published in 1979. It brought you two prestigious awards and, in a way, made you a poet. After more than forty years, how do you look upon that first book? Is there anything you would like to tell its young author?

CR: There was a time when I feared looking at that book. For instance, when my editor at Faber, Paul Keegan, suggested I put together a volume of Selected Poems, I was initially reluctant and kept saying no; but eventually he convinced me, and when I came to face the task of choosing poems from Arcadia I was less disgusted with what I found there than I had expected. Some of the poems I could now see had an appealing recklessness and excess that were missing from my more mature work. Even the mistakes I was making then struck me as having a certain bravery and honesty. Not all, but some. Consequently, the young author, with whom I'd been out of touch for so long, ended up telling the older one a thing or two that he needed to be reminded of - the excitement of finding one's own path, even at the risk of stumbling or losing one's way, might be one of them. 


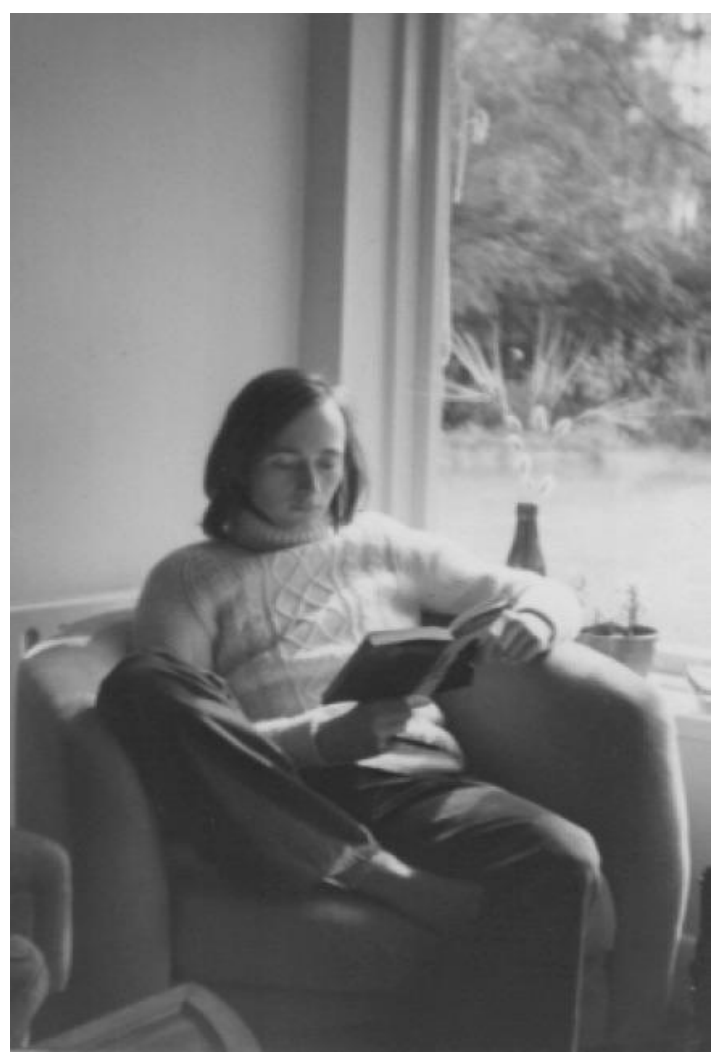

In his parents' sitting room, ca. 1971

JG: You were cited as a co-founder (with Craig Raine) of the Martian school of poetry. That was in the late 1970s, at the time of publishing Arcadia and Pea Soup, your second volume. Did you and Raine know each other then? Did the Martian label make sense to you? Was it helpful in any ways?

CR: Craig was very much my mentor in those early days. He had extraordinarily clear and firm ideas about what poetry could and should do, particularly when it came to his own version of Rimbaud's 'dérèglement de tous les sens', which he sought to achieve through what you might call a maximalist use of metaphor. There was nothing that could not be made more vivid in a poem by the application of a startling metaphor or simile - that would be a crude way of putting it. I was hugely attracted by this and did what I could to follow Craig's example. He is five years older than I am, and had taught me certain subjects - the Romantic poets, among them - when I was an Oxford student. After I graduated, I stayed living in Oxford and we became friends, showing each other our new poems, his on-the-spot critical comments always more trenchant and illuminating than mine. There was never any notion, though, of setting up our market stall as a 'school' of poetry, and the Martian label, when it was applied to us by a witty critic, was at best an irrelevance, at worst a nuisance. Still, it has stuck and will probably 
never be erased from the relevant paragraphs or footnotes in the literary histories of the period.

JG: And then (1985) you published Katerina Brac, a rather surprising book. It consists of fake translations from a fictional Eastern European poet (Brac) and, among other things, offers a compelling example of impersonal, or maybe double, poetic mode. I'm just wondering how those poems came about. Was it due to the (relative) popularity of some Eastern European poets in Great Britain at that time? Were you somehow relating to the political situation in places like Poland (censorship, political opposition, etc.)?

CR: I had two books out in the world, Arcadia and Pea Soup, both in what you might call the Martian manner, and I was trying to write new poems, only they all seemed to me unsatisfactory, not worth even finishing. They felt like self-imitation, second-hand, lazily derivative of my own past work - and who needed that? I certainly didn't. This went on for two years. Then one day I had the bright idea that the way not to imitate myself was to write somebody else's poems, and the figure of Katerina started to grow in my mind. Actually, at first, I thought I might write the poems of three different poets, two men and a woman, and have some unstated story in the background to connect them, a buried narrative which an attentive reader might puzzle out; but that would have been much too tricksy and the two men became irrelevant as soon as I started on Katerina. Her poems came quickly and the whole book was done in a month. All that month, she was an overpowering presence in my imagination. The great thing was that she wasn't me; she wasn't even a mask for my true, uninteresting self; she was out there beyond me and I was merely at her service, as translator. Where she came from and what language she was writing in were, to begin with, intended to be a mystery, but gradually, poem by poem, it grew obvious that she must be from somewhere in Eastern Europe. Nothing more specific than that, though. Her origin was in the books of poems by Herbert, Holub, Popa, Akhmatova, Grass and others that came out in the late sixties and early seventies in the Penguin series called Modern European Poets. Many of these poets were from behind what was then referred to as the 'Iron Curtain', and the urgency and thrill that the editors of the series and the translators of each volume evidently felt about bringing their work to an English readership was infectious. This was poetry as hot news, quite different from the old news that I was supposed to be concerned with as a student of the Oxford English Language and Literature course. I was not a happy student, out of my depth and out of sympathy with academic modes of critical discourse, but I felt I could understand, in my own terms, what these Modern Europeans had to tell me. So I was nourished by them at a time of need. And the memory of them continued to nourish me as Katerina took shape. Catching the note of translation, whereby the English text necessarily leaves the reader wondering about the greater richness or subtlety of the foreign language behind it, was a technical challenge that also kept me going. The question of politics, which you rightly raise, is more difficult to answer. Plainly, the political situation in Eastern Europe at that historical moment could not be directly translated into any British experience; but what I think I can say is that the obliqueness, the use of classical analogies and sly parables, that a poet like Zbigniew Herbert resorted to, so as to evade the censors, had a strong appeal - perhaps for psychological reasons too deep for me to understand. 
JG: As you know, Katerina Brac was translated into Polish by Leszek Engelking and Jerzy Jarniewicz (it was thus a translation of a translation - quite a giddy enterprise). And recently Simon Armitage has published a collection of poems about an imaginary mid-European state of Ysp, its leading poet HK and a young aspiring student Katerina Brac (,, herself something of an enigma," as it is stated in an anonymous introduction to the volume); there is also a poem about Brac (, Visiting Katerina Brac”). This must have been something of a surprise to you, I suppose?

CR: I haven't seen this book of Simon's, though he did show me the poem you mention some while ago - I suppose, to check that I was happy with it. Or not unhappy. Actually, I was delighted, not least to find that thirty years after her first and only appearence in English she still occupied a small niche in the imagination of a younger poet whom I happen to admire hugely. Now that you've told me about Ysp and HK, I must run out and buy a copy. As for my Polish book, it was brave of Jerzy and Leszek to take it on: they are the only translators in any language to have attempted it. Because I don't speak or read Polish, I have no idea how they met the challenge of translating from a 'translation', but I hope they had fun and allowed themselves to be inventive in their own style.

JG: Talking about translations... one can find in your books a number of English versions of French and Russian poems but they are always marked as imitations and not proper (literal) translations - there are poems written ,after Rimbaud,", after Mallarmé," etc. Do you think translating poetry word for word is a risky business?

CR: I am in awe of genuine translators, those who go to original texts with the purpose of introducing foreign poets to readers of English, and whose ideal is to stay faithful to the original while also making an acceptable English poem of it. I'm thinking of poet-translators as different as George Szirtes, Robert Chandler, Will Stone... What they do cannot be too highly valued. I don't know any foreign language with the sort of intimacy that would allow me to perform that service. But I do have a hunger for what is foreign and my way of satisfying it is to absorb it at one remove, through already existing translations - wherever possible with the foreign text alongside - and to see how much better I can get to know it through reworking it in my own poetic terms. I am aware that this practice is open to objection; in fact, it probably should be objected to! Some years ago I was invited by Jamie McKendrick to contribute some 'translations' (my inverted commas) to the Faber Book of Twentieth-Century Italian Poetry which he was editing. He supplied literal English versions to work from. One poem I took on was Montale's 'Eastbourne'. For the reader who knows the unexciting South Coast town of Eastbourne, the title could be thought to have an irredeemably bathetic quality, and yet the poem describes a moment of supreme significance to the poet, the return after a period of torpor of his lost poetic voice. I hope I made a respectable job of it. More recently, I was tempted to put my version of 'Eastbourne' into the collection of my poems that is due to be published later this year, and which includes a fair number of poems with English place names in the title. I almost did put it in, but then it struck me, in the nick of time, that I had no right to appropriate Montale's personal epiphany and present it as if it reflected any experience of my own. It was all right in the context of Jamie's anthology, but it would have been all wrong for my own book. I tend to regard what I produce in this 
line as 'appropriation' rather than 'translation', but even the business of appropriating needs to be justifiable.

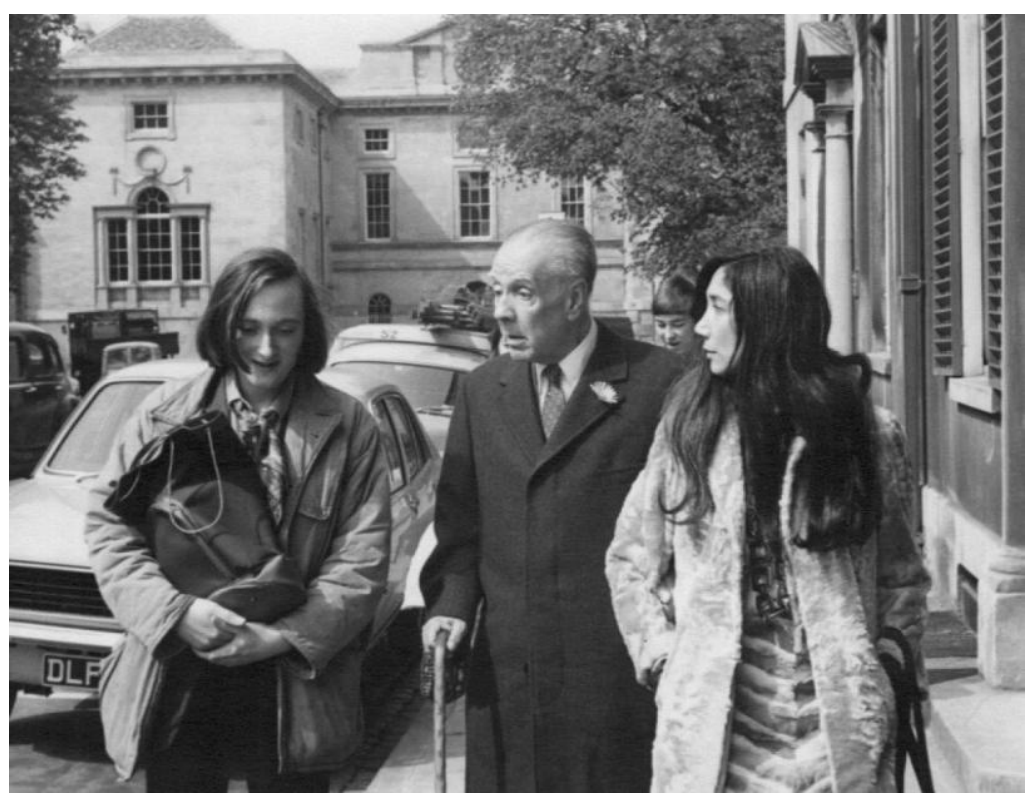

Walking with J. L. Borges, 1971

JG: You seem to like the idea of the poem as based on a meter, with a discernible rhyming scheme and a clear stanzaic pattern. Do you think such formal constraints are helpful in writing?

CR: Yes, rhyme, a more or less regular beat, and stanzaic patterning are old habits of mine. As are other kinds of patterning: assonance, alliteration, and so on. And yes, I do find them helpful. They keep me questioning and searching. I like to have a double challenge on the go: to say what I want to say, or perhaps to find what I want to say, in a way that is both natural and vivid. Those discoveries you make while, for instance, looking for a rhyme are themselves acts of spontaneity, pouncings and seizings, and if a colloquial note can be struck in the process, that is more often than not the result of disguised artifice. I also write poems that don't depend on overtly formal procedures, and I have no argument in principle against those who forsake them altogether, only the danger can be flatness, dullness, the sort of monotony that any decent prose writer would take pains to avoid.

JG: And metaphors? They are important to you. I find your metaphors witty, amusing, precise, mysterious - but also inventive in that they help us see the world as it has never been before. Do they come spontaneously or do you have to forge them into shape? Is there a metaphor you are particularly proud of? 
CR: Thanks for that generous description of my metaphors. How do they come about? As often as not, from things I see while walking around, or wandering thoughts as I sit at my desk. There's no reliable method involved. Chance and accident do most of that work for me, though there are occasions when a deliberate search is involved. I don't know if this will throw any light, but I've recently been writing poems about my childhood, some of which was spent in foreign countries. My parents lived for a while in Qatar, and I wanted to catch the moment when my brother and I, coming on holiday from boarding school, encountered that intense heat for the first time. What I eventually arrived at was this quatrain:
After a long journey, of several flights, we knew our holiday had at last begun as we stepped out through the aircraft door and bumped our heads on the sun.

I tried all sorts of things before I got the final line. What made it right - for me, at least - was the physical comedy of it. The premise, the perception I started from, was that the heat of Qatar was something almost solid, but it took a lot of thinking to translate that into metaphor. A more usual procedure, though, is to work on the implications of a metaphor that has flashed on the mind without any premeditation. My new book is called The Late Sun and the title poem sprang from such a moment. I was on holiday in Granada, in southern Spain, and sitting on the balcony of our rented apartment, drinking my first coffee of the day, as the sun came up. The balcony had a grand view, of a large part of the city and the mountains beyond, and I suddenly thought of the light effects that the sun was producing as cinematography. Then the notion of the sun as a cinematographer, whose death I had just learned about by chancing on his obituary, immediately followed. It was all as rapid as that. You could hardly call it thinking. But it gave rise to a poem I'm glad to have written and, while I'd hesitate to nominate any of my metaphors as my favourite, I can say I was pleased with this one.

JG: Could you say something about the process of composition? What is the first impulse? A line? An image? An impression? Is it like a happy coincidence? And do you revise a lot?

CR: Usually a phrase or a line comes first, carrying its own suggestion of both logical and musical development. I very seldom start a poem from an 'idea', though it has happened. When the initial words, wherever they came from, have settled in my head long enough to generate phrases or lines that might go with them, or follow from them, I turn either to my notebook or to the computer. After that, there's much fussing and fiddling, revising indeed, which could go on even after I've arrived at a stable shape for the poem. I tend not to think of a poem as finished until final proofs have been corrected and sent to the printer, and even then I have sometimes itched to continue the fussing and fiddling.

JG: You seem to enjoy narrative sequences and concept volumes, with poems being focused on a person or a motif, and in the form of variations on a theme. Katerina Brac, $\mathrm{Mr}$ Mouth and The Song of Lunch are the most obvious examples but an inclination to 
organize poems and fragments into unravelling narratives is felt almost everywhere in your books. Do you plan in advance to write a sequence or a story? Do you tell yourself "OK, now I'm going to write poems making up a story"?

CR: It seems to be a habit I've fallen into. My first two books were put together any old how, but from Katerina onwards I've liked to have what you might call a narrative shape in mind, either imposed from the outset or discovered in the process of composition. As I mentioned, the poems I've been writing in the last couple of months have been loosely about my childhood, which already suggests a beginning to any book that might eventuate, though how that book would resolve is wholly unclear at the moment. It could be all about childhood, but, equally, it could be a life story. That doesn't matter right now. What is helpful is to have some sort of germ, or seed, that it's my job to tend and nurture as it grows. Instinct, though, plays as big a part as planning. Or bigger.

JG: Do you feel a temptation to revise or somehow correct the poems written 30 or 40 years ago? We know poets who did this - Auden, for example.

CR: It's a temptation, as I've just suggested, but I resist it - by and large. But there are poems that haunt the conscience of the poet, crying out to be better than they are. I'm thinking now of a long poem, 'Survival: A Patchwork', in my book In the Echoey Tunnel. It was designed to celebrate the survival of my wife from her first clash with cancer. As well as being an actress, she made big, beautiful patchwork quilts from scraps of fabric picked up here and there, and I thought I might do the same in words; only it doesn't really come off because the scraps were not found but manufactured by me, and the result feels inauthentic. I long to repair the whole thing, but don't know how. In most other cases, I simply let poems continue to exist with all their blemishes and shortcomings. I love the story of Bonnard, who was seldom satisfied, smuggling paints and a brush into a museum where one of his canvases was hanging, and touching up a passage that was still bothering him while a friend distracted the museum guard. But I don't have that sort of perfectionism.

JG: There is a delightful musical adaptation of your poems - I'm thinking of Colin Matthews's orchestral and choral setting to Alphabicycle Order, a sequence of 26 short and fanciful pieces about imaginary creatures, places and objects. Could you say anything about it? I'm a great fan of Matthews and it was fun to see both of you working together.

CR: I'm glad you like Alphabicycle Order. It was Colin's idea. He had received a commission to write a piece for a new children's choir, associated with the Hallé Orchestra in Manchester, and my book happened to come out and catch his eye at about the time he was wondering what to do. My second collaboration with him, on No Man's Land, was different: again, he'd been commissioned, this time for a piece incorporating two male singers, a tenor and a baritone, with a small orchestra, and he wanted to address the subject of the First World War. So he talked to me and explained what sort of text he was hoping for. I'm afraid I misunderstood the brief, and went away and wrote words which were not at all what he'd had in mind but which he was kind enough to use anyway. I'm glad he did, not because of the value of the words themselves, but because 
he was able to make something so deeply moving out of them. It has one of the saddest, bleakest endings of any piece of modern music that I know. First you hear the old, sentimentally pumped-up recruiting song, 'We Don't Want to Lose You, but We Think You Ought to Go', being sung on a crackly antique gramophone by the original singer, then the voice is swallowed by the orchestra, before it too dissolves into wisps of disjointed phrases, then eerie silence. The audience on the first night was stunned and took a few moments before it could gather its applause. That was Colin's musical genius, nothing to do with my verses.

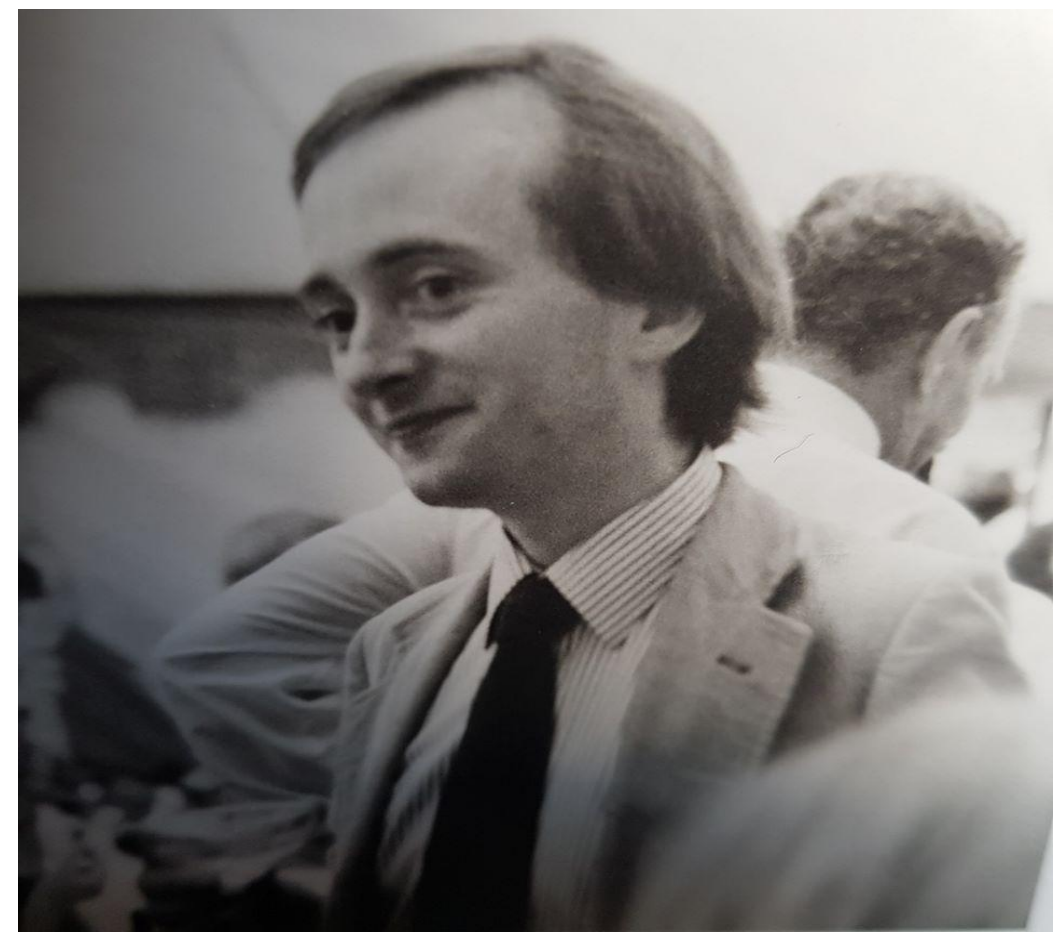

ca. 1980

JG: Are you a fan of contemporary music?

CR: Yes, I have always listened to new music with fascination, ever since schooldays. At school, I had a bunch of musical friends, more musical than I am, and we introduced one another to recordings of things we liked, particularly the twentieth-century classics. The first LP I ever bought was of Stravinsky's Rite of Spring. Then I went on to Bartók, Nielsen, Ravel, a wide range of others. And after that I got to know the living composers: Boulez, Berio, Birtwistle - and many more whose names don't begin with B. The London Sinfonietta had recently been formed and I went to quite a few of their concerts. My teens and twenties were my great time of discovery and enthusiasm, and I have to admit that I don't keep up so diligently these days, but I am an admirer of certain younger British composers like Mark Anthony Turnage, James McMillan and Thomas Adès. My 
very favourite late twentieth-century composer - and I don't say this to flatter your Polish readers - is Lutosławski. I love his sound world, the elegance of his orchestration and argumentation even when treating violent musical material, and what I'd risk calling the humanity of his major pieces. Perhaps just as I was fascinated by the Eastern European poets I have mentioned, I find something that speaks more than usually potently to me in the music of such composers as Lutosławski, Ligeti and Gubaidulina.

JG: The Song of Lunch, your 2009 book-length poem, was made into a short television drama starring Emma Thompson and Alan Rickman - a fascinating interpretation and (in my view) one of the best screen adaptations of contemporary poetry. The Song is a conspicuously personal poem and I'm wondering how it felt to hear your own voice transposed into other voices and accents. I imagine it must have been a pleasure - but wasn't it a bit disturbing, too? By the way, how did the idea of the movie come about and how did you manage to lure Thompson and Rickman?

CR: The idea was put to me by the actor and producer Greg Wise, who is married to Emma Thompson, who was a great friend of Alan Rickman, so the progress from conception to production was astonishingly smooth. Rapid, too. The BBC appeared to see the point of it at once and were nothing but enthusiastic and supportive. I suppose they thought of it as a slightly way-out experiment that might or might not come off, but with such a cast they were unlikely to be shamed by the result. Rickman was extraordinary: his voice is heard almost throughout, and his face is seen in close-up for minutes at a time, but the variety he brought to both pitching the words and summoning appropriate facial expressions for unspoken thoughts - unspoken but heard by the audience - was breathtaking. He was a great actor and it was a joy to have him and Emma Thompson animating my text. Since the film, I should add, there has been an equally fine theatrical performance of The Song of Lunch, with Robert Bathurst in the part of the hapless luncher. Robert approaches it quite differently, making more of the comedy than Rickman did, but without losing any of the pathos. He performs it as part of a double-bill, with $A$ Scattering as first half of the programme. Its first London production opened in February at the Riverside Studios in Hammersmith, but had to close after three weeks because of coronavirus. It was Robert who first thought of putting the two books together like that and whose energy has carried the production from its first try-out in Chichester five years ago to this curtailed run at the Riverside, and I don't believe he'll leave there; in fact I know he's already planning a revival, whenever so-called normal life resumes. You ask if watching these dramatisations is disturbing. I don't find it so at all. I'm certainly not the protagonist of The Song of Lunch - as you may be relieved to hear - and almost the same could be said of the 'I' in A Scattering, when objectively presented on the stage.

JG: What do you think of the two poems being put together and presented in this order? It's not at all obvious to start a dramatic performance with A Scattering, which is an elegy, and then move on to a lunch poem (even if it's a sad lunch poem).

CR: I think it works because, in effect, they tell the same story, albeit by different, even opposite, means. Robert spotted that. But when he did so, what he didn't know was that the day after I'd completed A Scattering, the very next day, I started work on The Song of 
Lunch. As I did, I had no notion that the two were to be connected in any way, and that Lunch, which I initially conceived as a light-hearted comedy, a well-earned holiday from the grief I had been writing about, would turn out to be a retelling of the Orpheus and Eurydice myth, and that there would inevitably be a lot of darkness in it. It's still a comedy, of course, but of a more ferocious kind than I first planned. Perhaps because Robert is the protagonist in both pieces, audiences can see straight away how intimately they belong together. It doesn't necessarily make for a comfortable evening in the theatre, but the dramatic impact speaks for itself.

JG: A Scattering, an award-winning book of elegies written after the death of your wife and in her memory, starts with recollections of your trip to Crete and includes references to the Cretan myth of Theseus, Ariadne and Minotaur; there is also a poem alluding to the myth of Orpheus (if my interpretation of the lines "A man with long garment/ is playing guitar/ in a field full of birds" is correct). This is a painful book and myths seem to provide you with a defence against and a rationale for pain...

CR: You know, I wasn't thinking of Orpheus when I described the man with the lyre, even if the field was full of birds, but you're absolutely right to describe my treatment of mythology as you do. The preceding poem, alluding to the Minotaur, admits as much: instead of facing the fact of Lucinda's imminent death, I start fiddling around with myths. And I apologise for it. 'Flowers of Crete' can be read as an extended apology to her - for not looking at her predicament squarely.

JG: "Professor Winterthorn's Journey," a long poetic sequence which opens your 2012 volume Nonsense, is still another attempt to cope with a sense of bereavement. It tells a story of a renowned scholar's trip to a conference in an overseas country; he meets some ghosts of his past, including the memory of his dead wife, and has an epiphanic experience in front of the sea: "Professor A. J. Winterthorn// stares into the mild, blue yonder.// And the yonder stares back." Would it be correct to say that the poem is a record of one person's coming to terms with his loss?

CR: Yes. Professor Winterthorn isn't me, exactly, but I found him a useful devise for carrying a story that resembled my own. Shortly before writing the poem, I had been to Wellington, New Zealand, at the invitation of the brilliant and generous poet Bill Manhire. At that time, 2009, he ran a department at the University of Victoria which invited writers from distant parts of the world to spend a week or so talking to students and giving readings. Obviously, the students get a large benefit, but so do the writers, and in my case the invitation came at the perfect moment, just as I was running away from Hull after my two unsatisfactory years there pretending to be a Professor. Wellington is an enchanting city, small, cosmopolitan, maritime, enclosed by hills - altogether congenial. And the new people I met were delightful as well. No doubt I romanticise it somewhat, but I had both a busy and a self-indulgent stay, and for the first time since Lucinda's death I began to feel less driven by grief. I relaxed. It wasn't an answer to my problems, but it was calming. So my hero Winterthorn, who may be a 'renowned scholar' but who has a lot of comically preposterous intellectual notions spinning around in his brain, flies to an unnamed foreign city to participate in an academic conference, meets, as you say, certain ghosts from the past, not least the ghost of his dead wife, feels his inner 
turmoil exacerbated by the academic shenanigans around him, and finally makes a dash for the pleasant little harbour where he can sit down and simply gaze at the sea. He hasn't resolved anything, but he's allowing himself a pause. So by writing the poem I suppose I was allowing myself a pause. A sort of literary self-therapy, which I could only justify if I made my protagonist a bit of a clown, as well as a figure to be pitied.

\section{JG: You are preparing a new book of poems...}

CR: It's largely elegiac. Friends have been dying and need to be written about. There are poems prompted my mother's death. She had a long, remarkably international life: born in East London, then almost immediately whisked off to Hong Kong, where she spent her childhood, and after that moving around the world as my father took jobs in hot places like Aden and Colombo, before settling back in Britain. I can't match her for breadth of travel, but there are poems about my own holiday wanderings in places like Greece, Venice and, particularly, Andalusia. My wife and I have got into the habit of spending a month each year in Granada, and in spite of the rampaging virus we're still hoping to get there this year. As the folly of Brexit has marched forward, I've found myself thinking more and more earnestly and hopelessly about the ideals of internationalism, the erasure of borders and sharing of cultures - all the things my Brexit-supporting fellow-countrymen and the Tory government oppose - and some of my new poems address that quietly. And there are poems about London, where I live and which I continue to want to celebrate, in spite of everything. So places figure largely, at home and abroad, but people as well.

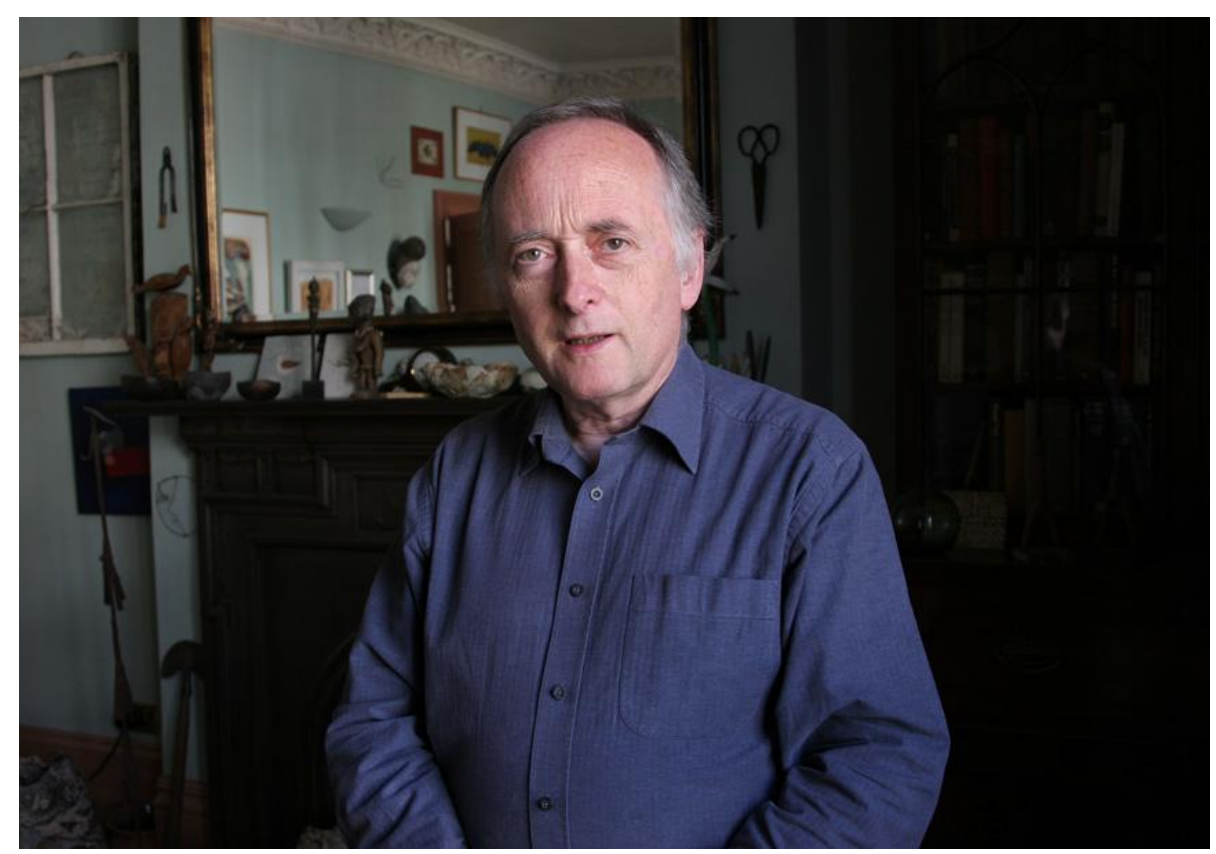

ca. 2010 (photo by Jeminah Kuhfeld) 
INTERVIEWEE'S BIO: Christopher Reid (b. 1949) is a British poet, essayist and translator. After graduating from Oxford University in 1971 he worked as a freelance journalist and a book review editor. He debuted with the 1979 volume Arcadia and has since published many books of poems (including three collections for children), with many awards to his name (Somerset Maugham Award, Hawthornden Prize and the Costa Book Award, to mention just a few). He has worked as poetry editor at Faber and Faber (where he edited two anthologies: Sounds Good: 101 Poems to be Heard, 1998, and Not to Speak of the Dog: 101 Short Stories in Verse, 2000) and Professor of Creative Writing at the University of Hull. His edition of Letters of Ted Hughes appeared in 2007. His latest collections are Nonsense (2012), Anniversary (2015) and Old Toffer's Book of Consequential Dogs (2018), a companion book to T.S. Eliot's Old Possum's Practical Cats.

E-MAIL: xopherreid@btinternet.com

INTERVIEWER'S BIO: Jacek Gutorow teaches Anglo-American literature at the University of Opole. His interests gravitate towards American and British modernism but he also writes extensively on contemporary Polish literature. He is the author of seven critical books (most recently Peknięty krysztat. Szkice o modernistach, The Flawed Crystal. Essays on the Modernists, 2019) and seven collections of poems. He has translated American and British authors (Henry James, Wallace Stevens, John Ashbery, Charles Tomlinson and others). Currently he is working on a monograph devoted to Henry James's late works.

E-MAIL: gutorow@uni.opole.pl 